\title{
The distribution of blood flow to the reproductive organs of rats near term
}

\author{
N. W. Bruce* \\ Nuffield Institute for Medical Research, University of Oxford, \\ Headley Way, Headington, Oxford OX3 $9 D S$, U.K.
}

\begin{abstract}
Summary. The rate of ovarian and utero-placental blood flow through vessels of less than $25 \mu \mathrm{m}$ diameter was examined with radioactive microspheres in 5 non-pregnant rats and 19 rats at Day 22 of pregnancy. Total blood flow to the reproductive organs was $0.559 \mathrm{ml} / \mathrm{min}$ in the non-pregnant animals and $13.2 \mathrm{ml} / \mathrm{min}$ in those near term, a 23-fold difference. The mean ovarian blood flow was high and increased from $\mathbf{0 \cdot 2 0 2}$ $\mathrm{ml} / \mathrm{min}$ to $0.845 \mathrm{ml} / \mathrm{min}$. Myometrial and endometrial blood flow increased from 0.156 to $2.24 \mathrm{ml} / \mathrm{min}$. The mean maternal placental blood flow at Day 22 of pregnancy was $0.76 \mathrm{ml} / \mathrm{min}$ or $121 \mathrm{ml} . \mathrm{min}^{-1} .100 \mathrm{~g}^{-1}$. Litter size was negatively correlated with mean fetal weight but showed little relationship to mean placental weight or to mean maternal placental blood flow.
\end{abstract}

\section{Introduction}

The rat is frequently used for research in reproductive biology yet little is known of the rate of blood flow through its reproductive organs during gestation. Fajer \& Barraclough (1967) measured ovarian venous outflow in non-pregnant and pregnant rats and reported that flow rates were extremely variable, between 0.06 and $0.35 \mathrm{ml} / \mathrm{min}$, and did not increase in pregnancy. Csepli, Menyhart, Lengyel, Bodnar \& Turoczi (1968) measured blood flows with a radioactive indicator-fractionation technique and found that total flow to the uterus and contents increased from $0.16 \mathrm{ml} / \mathrm{min}$ in non-pregnant rats to $2.09 \mathrm{ml} / \mathrm{min}$ in rats near term. These rates of ovarian and uterine blood flow are considerably lower, per unit weight of tissue, than those measured with radioactive microspheres in the rabbit (Abdul-Karim \& Bruce, 1973; Bruce \& Abdul-Karim, 1973). In the present work radioactive microspheres were used to re-examine ovarian and utero-placental blood flows in the rat.

\section{Materials and Methods}

Nulliparous, Albino Wistar rats with a mean weight of $270 \mathrm{~g}$ were paired with males overnight and vaginal smears were taken each morning. The day on which spermatozoa were found was called Day 1 of gestation: rats from this colony normally litter on the morning of Day 23 .

To measure blood flows, each rat was anaesthetized with an i.p. injection of $40 \mathrm{mg}$ sodium pentobarbitone $/ \mathrm{kg}$. Cannulae $(0.5 \mathrm{~mm}$ o.d. $\times 0.3 \mathrm{~mm}$ i.d.) were then inserted into the left and right femoral arteries for a distance of about $3 \mathrm{~mm}$, and into the left ventricle via the right common carotid artery. For the initial validation trials a cannula was also inserted into the left brachial artery. The cannulae were filled with saline only and no heparin was administered. The rat was kept prone for the duration of the experiment. The left femoral arterial cannula was connected to a pressure recorder and pulse-rate meter and the right femoral arterial cannula was connected to a syringe for blood withdrawal. An injection syringe containing 60,000 (range 40,000-90,000) microspheres (Minnesota Mining and Manufacturing Co.), $25 \mu \mathrm{m}$ diameter, labelled with ${ }^{46} \mathrm{Sc},{ }^{85} \mathrm{Sr}$ or ${ }^{51} \mathrm{Cr}$ and suspended in $0.5 \mathrm{ml}$ normal saline, was connected directly to the ventricular cannula and agitated continuously

* Present address: Department of Anatomy and Human Biology, University of Western Australia, Nedlands, Western Australia, 6009 Australia. 
to maintain an even dispersion of microspheres within the syringe. Withdrawal of blood at a steady rate of $0.5 \mathrm{ml} / \mathrm{min}$ from the right femoral and, when cannulated, the left brachial artery was commenced. After $5 \mathrm{sec}$ the microspheres were steadily injected during a period of $20 \mathrm{sec}$. Blood withdrawal was continued throughout the microsphere injection and for a further $20 \mathrm{sec}$. The cannulae were then flushed with saline in preparation for a second injection of microspheres or the rat was killed with an overdose of sodium pentobarbitone and dissected. Radioactivities of the blood samples and individual organs and tissues were measured and organ and tissue blood flows calculated as described previously (Bruce \& Abdul-Karim, 1973).

\section{Validation of technique}

To assess the variation due to technical errors of measurement, two batches of microspheres were injected simultaneously into each of 5 non-pregnant rats. The difference in estimates of ovarian flow between each batch of microspheres was only $4 \cdot 7 \%$ (range $0-9 \cdot 2 \%, n=10)$. In organs with higher flow rates the $\%$ differences were substantially less. In 7 rats given a total of 14 microsphere injections the correlation $(r)$ between the left brachial and right femoral arterial sample radioactivities was 0.99. For blood flows to the left and right kidney, $r=0.959(n=29)$ and for those to the left and right sides of the brain, $r=0.912(n=18)$. These results indicate an even bilateral and longitudinal distribution of microspheres in the general circulation. The fraction of the cardiac output apparently distributed to the lungs was $2.08 \pm 0 \cdot 71 \%$ (S.E.M.) to non-pregnant rats and $4.18 \pm 0.31 \%$ to pregnant rats. The difference, $2 \cdot 1 \%$, was significant $(P<0 \cdot 01)$ and suggested that $2 \%$ or more of the cardiac output passed through arterio-venous shunts of greater than $25 \mu \mathrm{m}$ diameter in the pregnant rats. Flow rates in this paper therefore refer only to flow through vessels of $<25 \mu \mathrm{m}$ diameter.

Two injections of about 60,000 microspheres 30 min apart were given to 5 Day-22 pregnant rats. Between the first and second injections there was little change in arterial pressure or cardiac output, but there was a $30 \%$ decrease $(P<0.05)$ in kidney blood flow. There were considerable, though not significant, decreases in blood flow to the brain $(17 \%)$, ovary $(40 \%)$, myometrium $(35 \%)$ and placenta $(18 \%)$. The time between the induction of anaesthesia and the injection of microspheres was $45-130$ min and was not correlated with any of the parameters measured. In view of these findings, only the results from the first injection of microspheres were used in the present work. Further details on the validation and use of the radioactive microsphere technique, particularly on the optimal number and size of microspheres, have been given by Buckberg et al. (1971).

\section{Results}

Nineteen rats were examined on Day 22 of gestation. Five non-pregnant rats, judged to be in metoestrus or dioestrus by the small size of their uteri and lack of intraluminal fluid, were examined for comparison. The weights and blood flows of the organs examined are given in Table 1.

Total utero-ovarian blood flow was 23 -fold greater in the pregnant rats, and blood flow to the uterus plus contents, but excluding the ovaries, was 73-fold higher. Although the mean weight of a single ovary was $19 \%$ lighter (not significant) in the pregnant rats, the mean ovarian blood flow was more than four times greater. The weight of each uterine horn, i.e. myometrium and endometrium only, was closely related to the number of fetuses in the horn in 7 rats examined: horn weight $(\mathrm{g})=0.659+0.318$ (number of fetuses); $r=0.804 ; P<0.001$. However, the relationship between blood flow to the horn and the number of fetuses was not significant $(r=0 \cdot 360)$.

The number of live fetuses was $10-15$ and there was a significant negative regression of fetal weight on number in the litter: fetal weight $(\mathrm{g})=5.664-0.119$ (number in the litter); $r=-0.523$; $P<0.05(n=19)$, but there was no apparent relationship between mean placental weight $(r=-0.115)$ or mean placental blood flow $(r=-0.064)$ and the number of fetuses in the litter $(n=19)$.

\section{Discussion}

The values for cardiac output and organ blood flows of the non-pregnant rats in this study are in 
Table 1. Mean ( \pm S.E.M.) weights and blood flows to various organs in non-pregnant rats and rats at Day 22 of pregnancy

\begin{tabular}{|c|c|c|}
\hline & Non-pregnant & Pregnant \\
\hline No. of rats & 5 & 19 \\
\hline Maternal weight $(\mathrm{g})$ & $276 \pm 11 \cdot 3$ & $353 \pm 6 \cdot 5^{*}$ \\
\hline Arterial pressure $(\mathrm{mmHg})$ & $106 \pm 6 \cdot 8$ & $95 \pm 4 \cdot 4$ \\
\hline Cardiac output (ml/min) & $62 \cdot 4 \pm 8.9$ & $81 \cdot 1 \pm 11 \cdot 9$ \\
\hline Cardiac output (ml. $\left.\mathrm{min}^{-1} .100 \mathrm{~g}^{-1}\right)$ & $22 \cdot 8 \pm 3 \cdot 5$ & $23 \cdot 0 \pm 1 \cdot 0$ \\
\hline \multicolumn{3}{|l|}{ Brain } \\
\hline Weight (g) & $1 \cdot 75 \pm 0.09$ & $1.72 \pm 0.04$ \\
\hline Blood flow (ml. $\left.\mathrm{min}^{-1} .100 \mathrm{~g}^{-1}\right)$ & $76 \cdot 3 \pm 5 \cdot 2$ & $63 \cdot 2 \pm 4 \cdot 9$ \\
\hline \multicolumn{3}{|l|}{ Heart } \\
\hline Weight $(\mathrm{g})$ & $1 \cdot 26 \pm 0 \cdot 13$ & $1.09 \pm 0.05$ \\
\hline Blood flow (ml. $\left.\min ^{-1} \cdot 100 \mathrm{~g}^{-1}\right)$ & $359 \pm 37$ & $456 \pm 36$ \\
\hline \multicolumn{3}{|l|}{ Kidney } \\
\hline Weight (individual) (g) & $1.29 \pm 0.09$ & $1 \cdot 22 \pm 0.04$ \\
\hline Blood flow $\left(\mathrm{ml} . \mathrm{min}^{-1} .100 \mathrm{~g}^{-1}\right)$ & $217 \pm 44$ & $289 \pm 20$ \\
\hline Blood flow to both kidneys ( $\%$ cardiac output) & $8 \cdot 37 \pm 0.58$ & $8 \cdot 62 \pm 0 \cdot 40$ \\
\hline Litter size & & $12 \cdot 1 \pm 0.33$ \\
\hline Fetal (individual) weight (g) & & $4 \cdot 21 \pm 0.07$ \\
\hline \multicolumn{3}{|l|}{ Ovary (individual) } \\
\hline No. of corpora lutea & & $6.78 \pm 0.28$ \\
\hline Weight $(\mathrm{g})$ & $0.089 \pm 0.018$ & $0.072 \pm 0.004$ \\
\hline Blood flow $(\mathrm{ml} / \mathrm{min})$ & $0.202 \pm 0.037$ & $0.845 \pm 0.080$ \\
\hline Blood flow (ml. $\left.\min ^{-1} .100 \mathrm{~g}^{-1}\right)$ & $233 \pm 19$ & $1261 \pm 122^{*}$ \\
\hline \multicolumn{3}{|l|}{ Placenta (individual) } \\
\hline Weight $(g)$ & & $0.620 \pm 0.014$ \\
\hline Blood flow (ml/min) & & $0.760 \pm 0.059$ \\
\hline Blood flow $\left(\mathrm{ml} \cdot \mathrm{min}^{-1} \cdot 100 \mathrm{~g}^{-1}\right)$ & & $121 \pm 8 \cdot 0$ \\
\hline Total blood flow ( $\%$ cardiac output) & & $11 \cdot 3 \pm 0 \cdot 8$ \\
\hline \multicolumn{3}{|l|}{ Uterus $\dagger$} \\
\hline Weight (g) & $0.57 \pm 0.032$ & $6 \cdot 31 \pm 0.34^{*}$ \\
\hline Blood flow (ml/min) & $0.156 \pm 0.029$ & $2 \cdot 24 \pm 0 \cdot 24^{*}$ \\
\hline Blood flow (ml.min $\left.{ }^{-1} .100 \mathrm{~g}^{-1}\right)$ & $28 \cdot 2 \pm 5 \cdot 3$ & $36 \cdot 4 \pm 3 \cdot 8$ \\
\hline \multicolumn{3}{|l|}{ Ovaries + uterus (+placentae in pregnant rats) } \\
\hline Weight $(\mathrm{g})$ & $0.731 \pm 0.081$ & $13.9 \pm 0.73^{*}$ \\
\hline Blood flow $(\mathrm{ml} / \mathrm{min})$ & $0.559 \pm 0.122$ & $13 \cdot 2 \pm 0.95^{*}$ \\
\hline Blood flow ( $\%$ cardiac output) & $0.958 \pm 0.234$ & $16 \cdot 1 \pm 0 \cdot 87^{*}$ \\
\hline
\end{tabular}

* Values significantly different from those in non-pregnant rats, $P<0.001$ (unpaired $t$ test).

$\dagger$ Includes myometrium, endometrium, cervix, vagina and oviducts.

agreement with those reported by Sapirstein, Sapirstein \& Bredemeyer (1960) and Sasaki \& Wagner (1971), although the latter workers only expressed organ blood flows as percentages of the cardiac output. The $30 \%$ increase in cardiac output $(\mathrm{ml} / \mathrm{min})$ in the pregnant rats, though not significant, was similar to that reported by Csepli et al. (1968).

In a comparison of techniques in the rabbit, Janson \& Albrecht (1975) considered that radioactive microspheres provided a more accurate estimate of ovarian blood flow than those obtained by venous outflow or indicator-fractionation techniques. Venous outflow is frequently used to determine rates of ovarian progesterone production in the rat but there are considerable technical problems involved and flow rates have generally been low and inconsistent (Piacsek \& Huth, 1971). It is likely that a considerable proportion of the ovarian blood flow is not collected in this way or that the technique itself substantially reduces flow. The present measurements of ovarian blood flow were about 10-fold greater than those determined by venous outflow collection at an equivalent stage of gestation in the rat (Fajer \& Barraclough, 1967; Piacsek \& Huth, 1971).

The average rate of maternal blood flow $\left(\mathrm{ml} . \mathrm{min}^{-1} .100 \mathrm{~g}^{-1}\right)$ through each placenta in the rat, 121, is within the range of values reported for other animals: sheep, about 280 (Meschia \& Battaglia, 1973); man, about 50-100 (Assali, Dilts, Plentl, Kirschbaum \& Gross, 1968); rabbit, 50 (Duncan, 1969); and monkey, 50 (Lees, Hill, Oschner, Thomas \& Novy, 1971). These species differences in. 
flow rates could, in part, be due to differences in the efficiency of nutrient transfer across the placenta and to the different rates of relative growth of the fetus (Bruce \& Abdul-Karim, 1974).

The supply of nutrients to the fetus is limited by the rate of maternal placental blood flow, placental efficiency and the concentration of nutrients in the maternal arterial blood. Since litter size in the rat affected fetal weight but not placental weight (a crude index of placental efficiency) or placental blood flow, the reduction in fetal weight with increasing litter size was probably due to a reduction in the concentration of nutrients in the maternal blood.

The total blood flows to each horn excluding the ovary were $0.078 \mathrm{ml} / \mathrm{min}$ in non-pregnant rats and $5.707 \mathrm{ml} / \mathrm{min}$ at Day 22 . The equivalent values reported by Csepli et al. (1968) were $0.080 \mathrm{ml} / \mathrm{min}$ and $1.045 \mathrm{ml} / \mathrm{min}$, but an indicator-fractionation technique was used and transfer of radioactive tracer across the placenta may have influenced the results.

Each uterine horn is supplied by two major arteries, the uterine and the ovarian, and by minor anastomotic branches from the vaginal branch of the hypogastric artery. These arteries, in turn, supply the parametrial artery which runs parallel with the uterine horn and gives off segmental branches to the uterine wall and placentae when present. The present results indicate that average flow through the ovarian, uterine and anastomotic branches of the hypogastric artery increases by 23-fold during pregnancy and through parts of the parametrial and segmental arteries by 73-fold. The uterine and parametrial arterial diameters increase by $75 \%$ during pregnancy (G.N. Rudeforth $\&$ N. W. Bruce, unpublished) and the resistance to blood flow in these vessels would therefore be substantially reduced. Changes in the resistance to blood flow in other vessels and their importance in the overall control of the utero-ovarian circulation during pregnancy have yet to be determined.

I thank Professor G. S. Dawes for advice and encouragement and Mrs J. McCairns and Mr A Stevens for technical assistance. This work was supported by grants from the Medical Research Council and the Nuffield Committee for the Advancement of Medicine.

\section{References}

Abdul-Karim, R.W. \& Bruce, N. (1973) Blood flow to the ovary and corpus luteum at different stages of gestation in the rabbit. Fert. Steril. 24, 44 47.

Assali, N.S., Dilts, P.V., Plentl, A.A., Kirschbaum, T.H. \& Gross, S.J. (1968) Uteroplacental circulation. In The Biology of Gestation. Vol. I. The Maternal Organism, pp. 185-203. Ed. N. S. Assali. Academic Press, New York.

BRUCE, N.W. \& ABdul-Karim, R.W. (1973) Relationships between fetal weight, placental weight and maternal placental circulation in the rabbit at different stages of gestation. J. Reprod. Fert. 32, 15-24.

BRUCE, N.W. \& Abdul-Karim, R.W. (1974) Mechanisms controlling maternal placental circulation. Clin. Obstet. Gynecol. 17, 135-151.

Buckberg, G.D., Luck, J.C., Payne, D.B., Hoffman, J.I.E., ARChIE, J.P. \& FIXLER, D.E. (1971) Some sources of error in measuring regional blood flow with radioactive microspheres. $J$. appl. Physiol. 31, 598-604.

Csepli, J., Menyhart, J., Lengyel, S., Bodnar, J. \& Turoczr, F. (1968) Blood circulation in pregnant rats. II. Some features of uterine circulation during pregnancy. Acta chir. hung. 9, 143-153.

DunCan, S.L.B. (1969) The partition of uterine blood flow in the pregnant rabbit. $J$. Physiol., Lond. 204, 421-433.
Fajer, A.B. \& Barraclough, C.A. (1967) Ovarian secretion of progesterone and $20 \alpha$-hydroxypregn-4en-3-one during pseudopregnancy and pregnancy in rats. Endocrinology 81, 617-622.

JANson, P.O. \& AlBrecht, I. (1975) Methodological aspects of blood flow measurement in ovaries containing corpora lutea. J. appl. Physiol. 38, 288-293.

Lees, M.H., Hill, J.D., Ochsner, A.J., III, Thomas, C.L. \& NovY, M.J. (1971) Maternal placental and myometrial blood flow of the rhesus monkey during uterine contractions. Am.J. Obstet. Gynecol. 110, 68-81.

Meschia, G. \& Battaglia, F.C. (1973) Acute changes of oxygen pressure and the regulation of uterine blood flow. In Foetal and Neonatal Physiology, pp. 272-278. Eds K. S. Comline, K. W. Cross, G. S. Dawes \& P. W. Nathanielsz. Cambridge University Press.

Piacsex, B.E. \& Huth, J.F. (1971) Changes in ovarian venous blood flow following cannulation; effects of luteinizing hormone (LH) and antihistamine. Proc. Soc. exp. Biol. Med. 138, 1022-1024.

Sapirstein, L.A., Sapirstein, E.H. \& Bredemeyer, A. (1960) Effect of haemorrhage on the cardiac output and its distribution in the rat. Circulation Res. 8 , 135-148.

SASAKI, Y. \& WAGNer, H.N., JR (1971) Measurement of the distribution of cardiac output in unanesthetized rats. J. appl. Physiol. 30, 879-884. 